Mobilising collaborative consumption lifestyles: A comparative frame analysis of time banking

\begin{abstract}
In this paper we elaborate how the framing of lifestyle-based collaborative consumption impacts local mobilisation. We present time banking as a collaborative consumption lifestyle emerging from literatures on collaborative consumption and lifestyle movements. The cultural processes of meaning making and practices of framing, through which time banks mobilise constituents and entice collective action, are examined through naturally occurring text interpreted for diagnostic, prognostic and motivational framing. These three framing tasks further illuminate the change aimed for in local lifestyles. The data were collected from time banks in three European metropolitan areas. The findings highlight framing as a practice that challenges traditional monetised ideology of exchange in orthodox economic theory and the hegemonic understandings of consumption. This paper advances the recent discussions on lifestyle movements engaging in meaning creation practices impacting the everyday actions of consumers in local communities.
\end{abstract}

Keywords: Collaborative consumption, frame analysis, lifestyle, social movement, time bank 


\section{Mobilising collaborative consumption lifestyles: A comparative frame analysis of time banking}

Departing from the institutionalised understanding of consumption as the acquisition and use of marketplace offerings, consumption can also be seen as a particular way of mobilising collective action. Consumption forms a part of the politics of everyday life where the consumer as activist is changing the world with consumption choices (Fine, 2013; Gabriel and Lang, 2006; Ginsburg, 2005; Halkier and Holm 2008). This is to some extent captured in collaborative consumption, which represents an alternative economic model based on sharing access to resources, rather than ownership (Botsman, 2013; Bardhi and Eckhardt, 2012) in local lifestyles where consumption activities becomes collective action.

In the classical understanding, social movements engage in activities that draw on capacities and resources (McCarthy and Zald, 1977) and opportunities in the internal and external political field of movements (McAdam et al., 2001) to challenge authorities. Thus, typically, social movements research has been skewed towards the exclusion of culturalideational explanations of movements by giving prevalence to structural explanations of internal-organizational or external-political opportunities (Davis, 2002; Snow and Benford, 1992). However, the processes through which movements express their agency should be considered alongside these structural explorations (de Bakker et al., 2013). Particularly lifestyle movements respond to the impoverishment of everyday life attempting to impact cultural, economic and political practices (Haenfler et al., 2012).

One such local lifestyle movement is time banking. Time banking is an alternative currency whereby one person volunteers to work an hour for another person. This person is credited with one hour, which she or he can redeem for an hour of service from another volunteer in the system. By nature, time banks are communities of reciprocal exchange and inclusion, promoting social cohesion in local, collaborative communities (North, 2014; Seyfang, 2004). Exchange in time banking is a centrally co-ordinated effort to match needs and wants where members exchange these individually between themselves. Members receive an hour of credit for an hour of work they offer to someone within the community - exchange of services is thus based on ideals of reciprocity, communality, and equality. Communities exert time as currency, acknowledging the skills and capabilities of consumers as community participants. 
In this paper, we elaborate how the framing of lifestyle-based collaborative consumption impacts local mobilization. We consider forms of collaborative consumption as lifestyle-related social movements who 'consciously and actively promote a lifestyle, or way of life, as their primary means to foster social change' (Haenfler et al., 2012, pp. 2). Through collective forms of consumption, exchange, and valuation, time banks strive to transform the economy and society. Thus, we ask, how is the process of mobilizing in local communities is framed; that is, how are ideas, activities and goals substantiated to organise and mobilise constituents and resources in and around time banks?

We address these questions by performing a comparative frame analysis of three European urban time banks. Frames are schemata of interpretation that help individuals to locate, understand, and categorize the physical and social world around them. Hence, they are a way organize individuals' experience and guide their action (Goffman, 1974). Frames do this by focusing to and articulating what is relevant / irrelevant as well as reconstituting and transforming understandings of and relations between phenomena and people in the social surrounding (Snow, 2007). Frames thus play an important part in how we perceive, understand and act towards various objects and issues in the everyday. In sociological analysis, framing is most systematically used in social movement literature where frames understood in their motivating, persuading, and mobilising capacity (Benford and Snow, 2000; Snow, 2007).

We elaborate the signifying work of producing and maintaining meaning that resonates with constituencies, wider publics, and counteracts adversaries. The contribution of this paper is assigning a two-fold meaning in terms of theoretical-conceptual and empirical framing of collaborative lifestyle movements in local contexts. We illuminate how emergent theoretical conceptualizations of collaborative consumption and lifestyle movements generate meaning to time banking. Further, comparing different ways of organizing time banks as collaborative lifestyles illuminates a social movement character. According to Haenfler et al. (2012) the way in which lifestyle movements encourage adherents to everyday action demands further study. Our empirical comparative perspective heeds this call by highlighting the social imagination at work where lifestyle movements engage in framing.

\section{Theoretical framework}


With the interruption of the neoliberal capitalism crisis, a further crisis emerged, that of the social legitimacy of the traditional forms of the social organisation of production, access and distribution of resources, goods, and monetary value (Albo, 2013; Amable, 2011; Harvey, 2006; Silver, 2003). These crises brought about various disruptions of the everyday. Social movements fill and extend spaces of disruption in the everyday by means of creativity and self-organization. Social movements respond to the restrictive and problem-inducing (rather than problem-solving) capacity of free market activity that neoliberalism promotes (Connolly, 2013) through consumption.

Social movements typically emerge from outside of traditional institutional arrangements, acting on perceived or experienced grievance, and in doing so either challenge or defend existing systems of domination and authority (Buechler, 2011; Meyer, 2007). Accordingly, most current social movement theory is dominated by the idea of contentious politics and action with a political purpose. Snow (2004b) has suggested augmenting and broadening the conceptualization of social movements to encompass any action wherein significant numbers of individuals, in some degree of collective organization and continuity, undertake unusual action to disrupt (or maintain) any institution that represents a form of social domination.

Building on this notion, Haenfler et al. (2012) suggested lifestyle movements as a social movement subtype, which is oriented towards alternative ways of leading everyday lives. Central is identification with a chosen lifestyle and subsequent everyday life consumer choices. Lifestyle movements aim for social change through aggregated individual action (Collom, 2011; Della Porta and Diani, 2006; Haenfler et al., 2012). In lifestyle movements 'participation is (1) relatively individualized and private, (2) ongoing rather than episodic, and (3) aimed at changing cultural and economic practices rather than targeting the state' (Haenfler et al., 2012, pp. 6).

What follows is, that, firstly the individual consumer and his or her private everyday life become the central site of movement activity. The personal/private and collective expressions of action, change and identity become entwined in the everyday (Davis, 2002, Haenfler et al., 2012). Individually experienced challenges lead to organisation and mobilisation; for instance, when practices around everyday routines (Wahlen, 2011) are disrupted, individuals may respond to the changed rhythms in everyday life by mobilising (Borland and Sutton 2007; Trentmann, 2009). This confluence of the private and collective forms of action has long been overlooked (Davis, 2002, Haenfler et al., 2012; Snow, 2004b). 
Secondly, the continuous nature of lifestyle movements is manifested in routine activities that change modestly but gradually (Wahlen, 2011), and foreshadow a fluidity of organisation. Because consumers individually perform and live the movement in their everyday lives, the traditional understanding of formal organization is less dominant (Ahrne and Brunsson, 2011; Sutherland et al., 2013) and the movement can be considered to take on a variety of organizational forms (Snow, 2004b).

Thirdly, lifestyle movement groups focus on a 'morally coherent, personally gratifying lifestyle and identity’ (Haenfler et al., 2012, pp 3). Instead of political targets, lifestyle movements challenge authoritative cultural and economic systems. Efforts can thus be oriented towards various actors and fields in the society: markets, religion, communities, for-profit and non-profit organizations, and culture in general terms (Snow, 2004b). Beyond everyday experiences, mobilisation draws impetus from ideologies, values, and beliefs, and mobilising methods stem from a collective identity and understanding.

Various social movements begin with institutional failures. Where such failures disrupt the everyday, they concurrently generate new practices that create new localities of exchange (de Bakker et al., 2013; Rao et al., 2000). These new localities can be independent of their causes (the original disruption), but their temporal longevity depends on the general socio-political dynamics (Trentmann, 2009). Toward this final point, we examine collaborative consumption in time banking exemplifying lifestyle movements.

\section{Linking consumption and lifestyle in time banking}

Collaborative consumption associates lifestyle with alternative modes of resource allocation and exchange (Albinsson and Perera, 2012; Bardhi and Eckhardt, 2012; Botsman and Rogers, 2010). Its basic premise is rooted, on the one hand, in the dramatic changes in living conditions, and on the other, in the disillusionment with equitable conditions and relationships in the commercial marketplace. Botsman and Rogers (2010) conceptualize collaborative consumption as organized around shared material resources, redistribution, and collaborative lifestyles. Research about these alternative forms of exchange scrutinizes the social desirability and capacity of exchange relationships to construct and maintain social ties (Belk, 2010; Cheal, 1988; Weinberger and Wallendorf, 2012), and build solidarity with or without reciprocity (Ilmonen, 2011; Komter, 2005). Reciprocity in local communities not to a 
particular individual (e.g. previous exchange partners), but the entire community (cf. Sahlins, 1972).

Two particular elements are important to our conceptualization of collaborative consumption: a (partial) renunciation from traditional markets, and an emphasis on collective action. Firstly, consumption is not necessarily commercial (McGregor 2007), but emerges in the everyday, local context. Thus, 'the structure of community sustenance activities affects the spatio-temporal concurrence of families, peers and strangers in everyday life, generating the circumstances under which particular consumer activities occur' (Felson and Spaeth, 1978, pp. 616). Thus, there's a certain fluidity of collaboration within the sphere of family, neighbourhood and community. Secondly, consumption is collective. While consumption can be a solitary activity carrying pleasure in its privacy (Bauman, 2005), collaborative consumption also considers consumption practices as acts of collective resistance creating connections between the private/individual and public/collective aspects of consumption (cf. Holzer, 2006; Klintman, 2006).

In their approach to collaborative consumption, Botsman and Rogers (2010) consider complementary currencies as a form of collaborative lifestyle. Having gained prominence during the recent economic stagnation, these alternative exchange systems epitomize a utopian economic model without money providing a means of resilience to localities by strengthening the social grid (Dodd, 2005; Schroeder et al., 2011; Seyfang and Longhurst, 2013). The social creativity in time banking relates to generalised reciprocity and equality in the valuation of competences (North, 2014). Unlike in traditional capitalist systems, participants' skills are valued in time, not money, and the egalitarian principle of time banks stipulates that the time of all participants is in par, that is, equal status and equal footing.

In more detail, everyone has certain skills and competences to exchange and the traded competences enhance solidarity among participants. People reciprocate help in a wider community, and giving and taking between participants creates the community (North, 2014; Schroeder et al. 2011). People can give their time; earn credit for their activity, and then claim time of other people in return. Consumers benefit from learning new skills, friendship, and participating in the community. In the most successful cases, time banking communities become caring and sharing communities - real support systems for consumers that are not capable of caring for basic needs. For this reason, time banks can also be used as a way to regenerate local social fabric, e.g. in deprived urban neighbourhoods (Seyfang, 2004). 
In summary, time banks exist at the intersection of the private and public, individual and collective in consumption. Time banks can change local cultures, but they also aim to change political and economical problems. With regards to resisting social ills, "time banks operate within a framework which not only facilitates local resilience, but also creates space for asking why the need to be resilient has arisen' (Gregory, 2012, pp. 269). Beyond identifying problems, to endure local lifestyle movements need to elaborate solutions to these problems and mobilise action to reach the proposed solutions. This is the essence of framing and frame analysis, which we conducted in three European time banks in order to find out the cultural mechanisms used to substantiate ideas, activities and goals to organise and mobilise constituents and resources in and around time banks.

In the following, we first describe frame analysis as understood in contemporary social movement literature, and then discuss how this method was used for collecting and analysing data in our study.

\section{Method}

\section{Frame analysis}

Frames are a way of making sense of the social realities and the everyday. Framing and frame analysis in social movement theory relate to managing meanings events, activities, places and actors. Framing stands for the socio-cultural mechanisms used to motivate, persuade, and mobilize: collective action frames aim to mobilise ideas, attract and activate follower and bystanders, affect movement targets, and discourage opponents (Benford and Snow, 2000; Snow, 2004a). Frames as interpretative schema are polysemic in that they carry various possible interpretations for different actors in a social context thereby exhibiting the situated and negotiated dynamics of participant engagement and solidarity generation (Fantasia, 1988; Snow et al., 2013). This suggests that 'meanings are variably contestable and negotiable and thus open to debate and differential interpretation' (Snow et al., 2007, pp. 387).

Framing has a two-fold purpose: to generate affinity and to incite action. Core tasks entail three forms of framing (1) diagnostic framing that stands for problematizing and diagnosing a troublesome issue as well as focussing blame for this state of affairs; (2) prognostic framing that elaborates the remedial strategy and a solution, or at least some tactical action towards the desired goals; and, (3) motivational framing, which incites this 
action in movement participants (Benford and Snow, 2000; see also Cress and Snow, 2000 and Snow et al., 2007). Diagnostic and prognostic framing often go hand-in-hand, as the particularities of problems constrain possible solutions. Nevertheless, where problems and diagnostic framing may be shared, prognostic framing is contingent on environmental factors, such as institutional dynamics, opponents, public opinion, and media. (Benford and Snow, 2000) Finally, since participation is often less causal or homogenous, motivational framing renders action subjectively meaningful. It further aims to alleviate freeriding that would otherwise be detrimental towards movement activities (Olson, 1971).

As previously discussed, lifestyle movements are different from political social movements. Participation in lifestyle movements is not entirely motivated by political aims or political change (Haenfler et al., 2012; Snow, 2004). In order to achieve cultural change, it may be necessary for movements to 'align their activities within existing symbolic repertoires' (Snow et al., 2013, pp. 227). This means that lifestyle movements either reinterpret existing cultural resources to fit their goals and claims, or construct new, meaningful practices out of cultural repositories.

We conceive framing as a transformative practice intended to change and disrupt dominant institutions, including those institutions related to consumerism and consumption. Framing mobilizes to de-institutionalise old cultural beliefs, norms, and values, and to establish new ones (Katzenstein, 1990; Lawrence and Suddaby, 2006; Rao et al., 2000; Snow, 2004b). Framing in collaborative consumption lifestyles challenges markets and the consumer society as well as build new forms of social justice and local solidarity. While collaborative consumption does take place in the consumer society, it challenges the ways exchange relationships and interactions are structured in the everyday.

\section{Data collection and analysis}

We collected and analysed naturally occurring data from three European countries and particular urban conglomerations: The Hague (The Netherlands), Helsinki (Finland) and London (United Kingdom). Our empirical material consists of (a) data from time banks' websites and discussion boards including official documents - constitutions, and research/position papers, video clips - and (b) naturally occurring data, such as organizers' and members' discussions. We also utilised individual discussions and observations (see table $1)$. 
Table 1. Data sources - about here

Our sample is a criterion sample (Patton, 2002). Selection was based on the requirement of accessible online information including a website with documentation of the organization and its activities, a Facebook page, and possibly a Twitter account [1]. Per the convention for criterion sampling, sampled cases met similar criteria for presenting information on the time bank. Beyond the apparent geographic and cultural differences, the time banks in The Hague, Helsinki, and London are subject to different institutional opportunities and challenges, influencing their activities.

Analytically, we utilized an approach that concentrates on topics in discursive space. Snow et al. (2013, p. 8) define a discursive space as 'the total volume of discussion whatever its form (i.e. question, speech, answer)- in a given interactional encounter, meeting or broader social occasion that is or that can be bounded in time and space'. The topics allow for the identification, articulation and elaboration of frames used in mobilizing individuals and organizing communities. The assumption is that the discursive space for framing includes many articulated topics of various degrees of elaboration and ultimately a differing degree of salience, noticeablity, and relevance. We also compared time banks by analysing variation that may exist between the different urban locations, political contexts, and varying ideological groundings.

We documented the data on each time bank with particular emphasis on operational context and its opportunities and challenges. We coded discussed topics in the data according to the three core tasks of diagnostic, prognostic and motivational framing. Topics can refer to 'an issue, actor, figurehead, activity, or event suggested for discussion or actually being discussed' (Snow et al., 2013, pp. 229). Initially each author coded one of the time bank datasets, after which categories were cross-compared across data sets in successive rounds of analysis; thus, each researcher was versed in the entire data set and could confirm or contradict the outcomes of coding. This investigator triangulation (Denzin, 2007; Patton, 2002) aimed to establish an in-depth understanding of the frames in this context. During data collection and coding, the identified frames were allowed to overlap, co-occur, and concomitantly elaborate the subsequent frames. The results are presented in the following section. 


\section{Results}

In the following text, we present the three empirical cases from the Netherlands, Finland and the United Kingdom, in that order. We first consider organisational forms and environments of operation. Then, we elaborate how these time banks utilise framing in different settings. Finally, we consider the extent to which the time banks investigated represent a collaborative lifestyle movement as conceptually outlined above.

\section{Organizational Profile of Three Time Banks}

Table 2. The time banks studied. - about here

Timebank.cc The artists Anton Vidokle and Julieta Aranda founded Timebank.cc under the umbrella of its predecessor "time/bank by e-flux." The Dutch branch of their time bank was opened in May 2011. The distrust of existing financial and economic systems, and the radical cuts in art funding, were an important driving force behind their initiative. In June 2013, the Dutch branch of the "time/bank by e-flux" became an independent association. The branch had then outgrown the stage of an experimental and artistic project. A more solid web infrastructure, economic model and legal structure were needed. By becoming an association, Timebank.cc sought to apply its democratic values to the administrative structure. Essential to the design of this community is a bottom-up approach (Timebank.cc, 2014).

Timebank.cc provides an online platform [1] that has more than 1200 members across the Netherlands. Additionally, members abroad opened a branch in Lisbon, Portugal. It is thus possible to exchange time credits across local communities, cities, and national boarders. For example, a Dutch person as a tourist in Lisbon can get a local tour guide paid in time bank hours. Time credits are accumulated by activity exchange, but also by working for the time bank. It is not possible to accumulate time debt: in order to receive service the member has first to give service. With this policy, the time bank aspires to avoid free riders. (Timebank Academy, March 13, 2014)

Although the time bank wants to create an alternative way of exchanging services along values departing with the capitalist market economy, there is simulation of economic 
institutions. The Board of the time bank decides the number of hours brought into circulation. The time bank thus issues time hours similar to a central bank issuing fiat currency. The time bank in The Hague issues time hours that members can spend for the bank, and accordingly can increase the number of hours in circulation. At this moment there are around 3000 hours in circulation, which means that on average each member has 3-5 hours in her or his time bank account. The functioning of time bank necessitates circulation of hours; saving time hours is not desired because it promotes fluctuation in time hour value. (Timebank Academy, March 13, 2014)

Stadin Aikapankki (STAP) The history of Finnish Stadin Aikapankki starts in 2009 as Kumpulan vaihtopiiri (Kumpula Exchange Circle). Initially, social and environmental concerns led to founding this time bank. The aim of STAP is to advance aid between people locally and thereby develop a more communal values-based culture around creation of the commons. Through its actions STAP wishes to strengthen the socially and ecologically just local economy.

The activity is based on the focal principles of equality, reciprocity, communality, sustainability and justice, participatory culture, autonomy, and co-operation. These principles stand for equal position of exchange partners, reciprocity in the community, and strengthening of communality between members, in neighbourhoods and society. All STAP activity starts with the members and rests upon their initiative. For instance, some activities are centred around organic local food production, recycling, and sharing as ways to reduce ecological impact. Actions of the time bank and the associated communities are autonomous, yet inclusive. STAP holds a sovereign standing in the Finnish society with regards to other societal actors; yet, everyone has the possibility to partake. (Stadin Aikapankki, 2014)

STAP operates without formal legal, fiscal and organizational structure, strictly outside the monetary economy. For instance, the aforementioned guiding principles prohibit financial transactions and the circulation of money in the time bank. Accordingly, STAP does not receive any grants or financial support for its activities. This practice is in line with the ideational guidance of the time bank, according to which the time bank exists for and through its members, and their work in the community, and is independent of other societal actors. External financing would introduce financial accounting standards and official structures, so it is eschewed. (R. van der Wekken, personal communication, March 11, 2014). 
Rushey Green Time Bank Established in 1999, Rushey Green Time Bank is clearly the oldest, but also the smallest time bank in our comparison. The time bank was registered as a charity in South London in 2004 (Timebanking UK, 2012). Its small size is partially due to its historical roots. The time bank began in a health-care setting connected to the Rushey Green Group Practice of health care providers. Thus, health-care specialists often refer new members to the time bank, whilst joining directly is also possible. According to their annual review, ending in March 2011, the time bank membership was 240 persons composing primarily women and having a strong representation of ethnical and disabled people (Rushey Green Time Bank, 2011)

The mission of the time bank connects general well-being through reciprocity, equity, trust, love, and care for each other within Catford (South East London). Healthy and productive relationships provide further incentive for environmental sustainability. Coproduction and reciprocity in this time bank mirror the constitution of the population in the area. Beyond capabilities, Rushey Green Time Bank explicitly discusses gender, sexuality, race, cultural background and religion related to equality, and mutual co-operation and understanding in the community. The community values respect, trust, empathy, confidentiality, integrity, and courtesy.

Rushey Green Time Bank has an official organizational structure as a company limited by guarantee. As such, it has to abide to regulations, such as relating to formal structures and a constitution, public disclosure of information, and refraining from certain political activities (The Charity Commission, 2014). As a charity, the Rushey Green Time Bank is financed with grants. In the annual report ending in March 2011, the time bank reported income of slightly over 91 thousand GBP (Rushey Green Time Bank, 2011).

\section{Comparing time banking frames in various settings}

Considering that the organizational forms and actions differ among these three time banks, can we expect variation in their ideational work? For instance, Stadin Aikapankki considers '[t]ime banking [as] an objection to everyone having to make it in life alone' (Stadin Aikapankki website, 2014). This idea encapsulates one of the foundational premises of time banking. It further embraces the nature of time banks as lifestyle movements inasmuch as 
time banking challenges the conventional individualised understanding of the contemporary way of life.

The following text highlights different frames emerging from topics in the empirical data. We outline our results as an array of framing tasks: (a) diagnostic framing that stands for problematizing and diagnosing a troublesome issue as well as assigning blame for this state of affairs; (b) prognostic framing as the remedial strategic and tactical action towards desired goals; and motivational framing, which incite this action in lifestyle movement participants (see table 3).

Table 3. Time banks' framing strategies - about here

Diagnostic framing - problematizing and diagnosing troublesome issues Various issues are considered problematic in current societies. Time banks and their participants address these problems. While problems differ in national as well as in local contexts, some problems are shared. Most prominently and consistent between time banks: the monetized market system becomes the main target of objection. In the Netherland/Dutch context, money forms restrictive boundaries to social activity and represents the pronounced 'root of all evil'. This sentiment is in correspondence to the time bank in the UK, Rushey Green, where the traditional monetary system conveys social inequality as illustrated by the following quote.

Perhaps we have lost something in the West. Our affluence has made it possible to buy our way out of community service, even though we complain bitterly about all the taxes we pay to local and state governments (Member 1, Rushey Green Facebook page, March 2013)

The fact that contemporary societies face several inequalities that do not only relate to the monetary system becomes evident looking at the Finnish time bank. STAP indicates, as guiding principles, parity, work equality, and the respect for others' work, as well as the point that everyone has resources. These issues indicate that the time bank in Helsinki wants to address social inequalities by community building. The same values underlie the Rushey Green (UK) time bank, to say that equality in building trustful communities where the 
background of participants does not matter. This value reifies a true diversity perspective, as promoting social cohesion seems to be missing in the contemporary society.

Another topic relating to community building and communality is health and wellbeing. Isolation and depression caused by loneliness, makes it vital for the time bank to bring people together in the neighbourhood. Money can be used to buy out of community services and those better off are more likely to acquire better services. Similarly, the state-market dichotomy is problematic where markets bring economic crises and the state is in withdrawal. Similar concerns, yet not central, arose for Timebank.cc in the Netherlands. Community building is important inasmuch as the time bank aims at strengthening the social fabric and well-being in communities and neighbourhoods. The debates in this Dutch time bank revolve around the valuation of and spaces for work. Work in the time bank is perceived as pegged to a promise of equality, and freedom away from money as a means of alienation and oppression.

Similarly related to valuation, an important and persisting matter in debates of the Finnish context is taxation. STAP considers that the nature of time banking sets it apart from professional work and taxable income. Correlating time banks with traditional monetary systems, through the equivalence of "tovi" time credit spent and earned with euro, is superimposing on time banking the terms of a monetary currency as well as treating time bank activities as tax avoidance. Taxation concerns were also in the British time bank by underlining that time banking can assist in the search for local sufficiency and abundance instead of being taxed by authority. The Dutch time bank has had consultations with the tax authorities; their activities are, however, not considered a 'societal problem' as Dutch tax law allows for tax-free voluntary activity.

Prognostic framing - remedial strategies, solutions, and tactical actions The strategic and tactical repertoires of the time banks in Finland, the Netherlands and the United Kingdom highlight various understandings on how to accomplish change through alternative models of exchange. What is common in all time banks in our study is the fact that time banking allows for co-production as depositories and catalysts of skills and resource. It is evident that individual action plays a central role on a one-to-one basis. The time banks also engage in strategic actions in order to strengthen local communities. 
The platform serves as a support for individuals and businesses. Lectures and meetings stimulate critical and decisive thinking about current economic systems (Timebank.cc website)

In the Netherlands, there are a live sessions with artists, an occasional time restaurant, where every member of the time bank is invited to donate food in return for time credit, and there is service bank, where members can get services, such as a haircut or bike repairs, in exchange for time credits. In the Netherlands, activities are diversified in a strategic search for new autonomy in the contemporary economic model by offering a diversified range of services to motivate circulation of time credits and to encourage regular exchanging.

In the UK, co-production builds the community, thereby keeping the time bank going in addition to exchanging services. Similar to the Netherlands, UK members engage in activities to recruit new members, to advance public relations, and to organise new projects. The time bank in the United Kingdom is active in reputation building, from receiving several awards for promoting health and sustainability in the local community to being associated with higher authorities, such as the National Health Service (NHS) and the local municipality. These alliances increase the institutionalisation and longevity of the time bank.

In the Finnish context, the transformational capacity of time banks is perceived in the potential for bringing about a paradigm change for a democratic society. Time banking is understood as bringing about change in the way work is valued. Time bank participants create trust through community-level reciprocity. STAP collaborates with local movements that promote ideas around sustainability (e.g., local and organic food initiatives) or alternative economic systems. Strategic network memberships and visibility allow longevity and hinder the state co-opting the movement. However, increased activity and level of politicisation has provoked a heated debate with the tax authorities. The resulting guidelines by the tax authorities on time bank activities have devastated the community [1].

Motivational framing - inciting action How action is enticed can be considered in relation to motivational framing. In the Finnish context, influencing the politico-economic decisions that are taking precedence in people's lives is beyond one person's ability, yet possible through time banking. A new culture of help, where all work is valuable, can be created without direct reciprocity or indebtedness. This culture includes, for instance, transmitting skills from the elderly to young people as an aspect of intergenerational cooperation that keeps retirees 
involved in societal activity and shows that they are still needed. Loneliness can be fought, and care provided, at the same instance.

But by together identifying on a local level as to what are the existing valuable instances and practices in our community we want to support and from there on expand the spaces for solidarity via a tool as Time banking ... we can have a real say in shaping our daily lives and our (global) community. (STAP website, Timebanking as an instrument for local democratic organising)

In the Dutch time bank, it is important to meet new people and accomplish something without using (or having) any ordinary money. As such, time banking is an alternative parallel economic system based on trust, conviviality, and interest in social exchange. Thus, the Hague time bank is not a reciprocal favour system, but a means for meeting other people and building relationships. By participating in time banking, it is possible to expand the professional as well as the personal network and meet interesting people that can help each other. Through involvement in time banking, personal lifestyles can be transformed and enhanced by offering a sustainable range of giving and receiving services.

In the UK case, care is framed as central to the motivation for time banking. This includes both care for the community as well as for the individual. The neighbourly support improves mental and physical well-being. Support is particularly useful for isolated elderly people or families. Moreover, participants with plenty of time but little money resource can find new contacts in the community and increase their self-esteem. The variety of groups and activities, such as the community garden or trips together, are important in keeping participants active and in creating a sense of community. Friendships are seen as a central way of becoming part of the community thereby also creating boundaries around the community.

\section{Discussion}

The idea of cultural and economic transformation is central to collaborative lifestyle movements of consumption. Time banking as alternative currency is in this study theoretically framed a particular example of collaborative consumption-based lifestyle movement. Collaborative consumption in time banks turns away from traditional commercial exchange and searches for the meaning in consumption processes through alternative paths in 
a shared lifestyle. Time banking seeks the common good locally for its members, thereby highlighting collective action in the traditional social movement sense. Within the community, members are simultaneously asset and the final consumers. This dichotomy represents an alternative way of organizing the everyday. Consumers, as time bank participants, are in search of alternative economic and cultural practices in individual activities of a shared lifestyle, which also stresses the collective feature of a time bank.

The individuals in their private everyday life are central to time banks and more generally in collaborative lifestyles. Sharing in the community is exemplified in motivational framing. Here the ability to change the everyday lives of members requires collaborative communal effort. The participants perform and live the movement in their everyday lives individually. Since lifestyle movements nevertheless tend to be ongoing, some level of organization needs to be attributed to them. At minimum, the time bank organization is present through brokering exchanges: organizational forms varied from no set structure (STAP) to formal charity status (Rushey Green).

Lifestyle movements mobilize action toward social change goals. Collective action frames and the actual reformative capacities of time banks to transform the status quo differ somewhat. How movements attempt to, and possibly succeed in, destabilizing authoritative institutions has to do with the local particularities as well as institutional challenges of the time banks. For instance, both The Hague and Helsinki time banks have an economic target for their activities. In The Hague, the original goal of changing the funding mechanisms for the arts community has been replaced by establishing a parallel economy along communal principle of sharing. In Helsinki, economic goals relate to reforming the monetary system by disassociating with it. Similarly, the Helsinki and London time banks share a strategy that stresses the cultural construction of an equalitarian community. Our findings are in agreement with the conceptualisation of lifestyle movements and the enlarged view of change agency oriented towards cultural and economic practices. From our data, we can argue that economic change is so fundamental in the time bank actions that it does generally differentiate between them.

\section{Conclusions}

This paper elaborates how the framing of lifestyle-based collaborative consumption impacts local mobilization. Considering time banking as a collaborative lifestyle movement, we argue 
that time banks unite individuals and communities in the creation of the commons, confronting the hegemonic models of economic activity, and instigating social change. Time banks are an organizational representation of what could be conceptualized as a collaborative lifestyle movement. Framing in a lifestyle movement is different to framing in traditional social movement setting, since the ideologies guiding individual activity aggregate on a collective level.

Through our study, we gain an understanding of the proclaimed local and societal implications of framing as a strategy and tactic of mobilising consumers and collaborative consumption lifestyles. Our research expands the discussion on lifestyle movements and the ways in which these movements enlist adherents in everyday action. Using the time banking as an illustrative example, we highlight the social imagination at work where collaborative lifestyle communities engage in framing for movement action. Such action challenges the dominant social order by opposing monetised ideology of exchange in orthodox economic theory and by engaging in alternative modes of exchange moving beyond hegemonic understanding of consumption.

\section{Notes}

[1] After the tax administration took on the time banks, STAP (as well as other Finnish time banks) has reported reduced number of exchanges and general member anxiety in the future of the activity (R. van der Wekken, personal communication, March 11, 2014). The diagnostic and prognostic framing in STAP therefore illustrates political agency reminiscent of a traditional social movement tactics. As the time bank has been scrutinised and penalised by the tax authorities, STAP framing also engenders policy issues.

\section{References}

Ahrne, G. \& Brunsson, N. (2011) Organization outside organizations: the significance of partial organization. Organization, 18 (1), 83-104.

Albo, G. (2013) The Crisis and Economic Alternatives. Socialist Register, 49, 1-25.

Albinsson, P.A. \& Perera, B.Y. (2012) Alternative marketplaces in the 21st century: Building community through sharing events. Journal of Consumer Behaviour, 11 (4), 303-315.

Amable, B. (2011) Morals and politics in the ideology of neo-liberalism. Socio-Economic Review, 9 (1), 3-30. 
Bardhi, F. \& Eckhardt, G.M. (2012) Access-Based Consumption: The Case of Car Sharing. Journal of Consumer Research, 39 (4), 881-898.

Bauman, Z. (2005) Work, Consumerism and the New Poor, 2nd edn. Open University Press, Maidenhead, UK.

Belk, R. (2010) Sharing. Journal of Consumer Research, 36 (5), 715-734.

Benford, R.D. \& Snow, D.A. (2000) Framing Processes and Social Movements: An Overview and Assessment. Annual Review of Sociology, 26, 611-639.

Borland, E. \& Sutton, B. (2007) Quotidian Disruption and Women's Activism in Times of Crisis, Argentina 2002-2003. Gender \& Society, 21 (5), 700-722.

Botsman, R. (2013) The sharing economy lacks a shared definition. [WWW document] URL: http://www.fastcoexist.com/3022028/the-sharing-economy-lacks-a-shareddefinition\#4 (accessed on February 27th, 2015)

Botsman, R. \& Rodgers, R. (2010) What's Mine is Yours: The Rise of Collaborative Consumption. HarperCollins, New York, NY, USA.

Buechler, S.M. (2011) Understanding Social Movements: Theories for the Classical Era to the Present. Paradigm Publishers, Boulder, CO, USA.

Charity Commission (2014) Set up a charity. [WWW document] URL: https://www.gov.uk/setting-up-charity (accessed on February 27th, 2015)

Cheal, D. (1988) The Gift Economy. Routledge, London, UK.

Collom, E. (2011) Motivations and Differential Participation in a Community Currency System: The Dynamics Within a Local Social Movement Organization. Sociological Forum, 26 (1), 144-168.

Connolly, W.E. (2013) The Fragility of Things. Duke University Press, Durham, NC, USA.

Cress, D.M. \& Snow, D.A. (2000) The Outcomes of Homeless Mobilization: The Influence of Organization, Disruption, Political Mediation, and Framing. American Journal of Sociology, 105 (4), 1063-1104.

Davis, J.E. (2002) Narrative and Social Movements: The Power of Stories. In: Stories of Change (ed. by J.E. Davis), pp. 3-29. State University of New York Press, Albany, NY, USA.

de Bakker, F.G.A., den Hond, F., King, B. \& Weber, K. (2013) Social Movements, Civil Society and Corporations: Taking Stock and Looking Ahead. Organization Studies, 34 (5-6), 573-593.

Della Porta, D. \& Diani, M. (2006) Social Movements, 2nd edn. Wiley, Chichester, UK.

Denzin, N.K. (2007) Triangulation. In: The Blackwell Encyclopedia of Sociology (ed. by G. Ritzer, G.), pp. 5083-5088. Blackwell, Malden, MA, USA.

Dodd, N. (2005) Reinventing monies in Europe. Economy and Society, 34 (4), 558-583.

Fantasia, R. (1988) Cultures of Solidarity. University of California Press, Berkeley, CA, USA.

Felson, M. \& Spaeth, J.E. (1978) Community Structure and Collaborative Consumption: A Routine Activity Approach. American Behavioral Scientist, 21 (4), 614-624.

Fine, B. (2013) Consumption matters. ephemera: theory \& politics in organization, 13 (2), 217-248. 
Ginsborg, P. (2005) The politics of everyday life: making choices, changing lives. Yale University Press, New Haven, CT, USA.

Goffman, E. (1986). Frame Analysis: An Essay on the Organization of Experience. Northeastern University Press, Boston, MA, USA.

Gregory, L. (2012) Improving health through participation: time banks as a site for coproduction. Ph.D thesis, Cardiff University, UK.

Halkier, B. \& Holm, L. (2008) Food consumption and political agency: on concerns and practices among Danish consumers. International Journal of Consumer Studies, 32 (6), 667-674.

Haenfler, R., Johnson, B. \& Jones, E. (2012) Lifestyle Movements: Exploring the Intersection of Lifestyle and Social Movements. Social Movement Studies, 11 (1), 1-20.

Harvey, D. (2005) A Brief History of Neoliberalism. Oxford University Press, Oxford, UK.

Holzer, B. (2006) Political consumerism between individual choice and collective action: social movements, role mobilization and signalling. International Journal of Consumer Studies, 30 (5), 405-415.

Ilmonen, K. (2011) A Social and Economic Theory of Consumption. Palgrave Macmillan, Basingstoke, UK.

Katzenstein, M.F. (1990). Feminism within American Institutions: Unobtrusive Mobilization in the 1980s. Signs, 16 (1), 27-54.

Komter, A. (2005) Social Solidarity and the Gift. Cambridge University Press, Cambridge, UK.

Klintman, M. (2006) Ambiguous framings of political consumerism: means or end, product or process orientation? International Journal of Consumer Studies, 30 (5), 427-438.

Lawrence, T.B. \& Suddaby, R. (2006) Institutions and institutional work. In: Handbook of Organization Studies (ed. by S.R. Clegg, C. Hardy, T.B. Lawrence \& W.R. Nord), pp. 215-254, 2nd edn. Sage, London, UK.

McAdam, D., Tarrow, S. and Tilly, C. (2001) Dynamics of Contention. Cambridge University Press, Cambridge, UK.

McCarthy, J.D. and Zald, M.N. (1977) Resource Mobilization and Social Movements: A Partial Theory. American Journal of Sociology, 82 (6), 1212-1241.

McGregor, S. (2007) Consumer scholarship and transdisciplinarity. International Journal of Consumer Studies, 31 (5), 487-495.

Meyer, D.S. (2007) The Politics of Protest: Social Movements in America. Oxford University Press, New York, NY, USA.

North, P. (2014) Complementary currencies. In: The Routledge Companion to Alternative Organization (ed. by M. Parker, G. Cheney, V. Fournier \& C. Land), pp. 182-194. Routledge, London, UK.

Olson, M. (1971) The Logic of Collective Action: Public Goods and the Theory of Groups. Harvard University Press, Cambridge, MA, USA.

Patton, M.Q. (2002) Qualitative Research \& Evaluation Methods, 3rd edn. Sage, Thousand Oaks, CA, USA. 
Rao, H., Morill, C. \& Zald, M.N. (2000) Power Plays: How Social Movements and Collective Action Create New Organizational Forms. In: Research in Organizational Behavior (ed. by B.M. Staw \& R.I. Sutton), pp. 237-281. Elsevier Science, New York, NY, USA.

Sahlins, M. (1972) Stoneage economics. Aldine, New York, NY, USA.

Schroeder, R.F.H., Miyazaki, Y. \& Fare, M. (2011) Community currency research: an analysis of the literature. International Journal of Community Currency Research, 15 (A), 31-41.

Seyfang, G. (2004). Working Outside the Box: Community Currencies, Time Banks and Social Inclusion. Journal of Social Policy, 33 (1), 49-71.

Seyfang, G. \& Longhurst, N. (2013) Growing green money? Mapping community currencies for sustainable development. Ecological Economics, 86, 65-77.

Silver, B. (2003) Forces of Labor. Cambridge University Press, Cambridge, UK.

Snow, D.A. (2004a) Framing Processes, Ideology, and Discursive Fields. In: The Blackwell Companion to Social Movements (ed. By D.A. Snow, S.A. Soule \& H. Kriesi), pp. 380-412. Blackwell, Malden, MA, USA.

Snow, D.A. (2004b) Social movements as challenges to authority: Resistance to an emerging conceptual hegemony. In: Authority in Contention (Research in Social Movements, Conflict, and Change, Volume 25) (ed. by D.J. Meyers \& D.M. Cress), pp. 3-25. JAI Press, Greenwich, CT, USA.

Snow, D.A. (2007) Frame. In: The Blackwell Encyclopedia of Sociology (ed. by G. Ritzer, G.), pp. 1778-1780. Blackwell, Malden, MA, USA.

Snow, D.A. \& Benford, R.D. (1992) Master Frames and Cycles of Protest. In: Frontiers in Social Movement Theory (ed. by A.D. Morris \& C. McClurg Mueller), pp. 133-173. Yale University Press, New Haven, CT, USA.

Snow, D.A., Tan, A.E. \& Owens, P.B. (2013) Social Movements, Framing Processes, and Cultural Revitalization and Fabrication. Mobilization, 18 (3), 225-242.

Snow, D.A., Vliegenthart, R. \& Corrigall-Brown, C. (2007) Framing the French Riots: A Comparative Study of Frame Variation. Social Forces, 86 (2), 385-415.

Sutherland, N., Land, C. \& Böhm, S. (2013) Anti-leaders(hip) in Social Movement Organizations: The case of autonomous grassroots groups. Organization, 21 (6), 759781.

Trentmann, F. (2009) Disruption is Normal: Blackouts, Breakdowns and the Elasticity of Everyday Life. In: Time, Consumption and Everyday Life: Practice, Materiality and Culture (ed. by E. Shove, F. Trentmann \& R. Wilk), pp. 67-84. Berg, Oxford, UK.

Wahlen, S. (2011) The routinely forgotten routine character of domestic practices. International Journal of Consumer Studies, 35 (5), 507-513.

Weinberger, M.F. \& Wallendorf, M. (2012) Intracommunity Gifting at the Intersection of Contemporary Moral \& Market Economies. Journal of Consumer Research, 39 (1), 74-92. 
Table 1 Data Sources

\begin{tabular}{|c|c|}
\hline \multicolumn{2}{|l|}{ Timebank.cc } \\
\hline Online & $\begin{array}{l}\text { timebank.cc } \\
\text { www.facebook.com/Timebank.cc } \\
\text { stroom.typepad.com/timebank } \\
\text { e-flux.com/timebank }\end{array}$ \\
\hline Personal contact & Timebank.cc Academy @ Stadslab, The Hague, March 13, 2014 \\
\hline \multicolumn{2}{|c|}{ Stadin Aikapankki (STAP) } \\
\hline Online & $\begin{array}{l}\text { stadinaikapankki.wordpress.com } \\
\text { www.facebook.com/pages/Stadin-Aikapankki/119314174764954 } \\
\underline{\text { twitter.com/stadiaikapankki }} \\
\underline{\text { aikaapankista.wordpress.com }}\end{array}$ \\
\hline Personal contact & Ruby van der Wekken, Helsinki, March 11, 2014 \\
\hline \multicolumn{2}{|c|}{ Rushey Green Time Bank } \\
\hline Online & $\begin{array}{l}\text { www.rgtb.org.uk } \\
\text { www.facebook.com/rusheygreen.timebank } \\
\underline{\text { twitter.com/RGTB }} \\
\text { www.timebanking.org }\end{array}$ \\
\hline Published material & $\begin{array}{l}\text { Rushey Green Time Bank (2011). Annual Review, April } 2010 \text { - March } \\
\text { 2011. [online]. Available at: } \\
\text { http://www.rgtb.org.uk/extras/Rushey\%20Green\%20Time\%20Bank\%2 } \\
\text { 0Annual\%20Review\%202010-2011.pdf. Accessed on December 30, } \\
2014 .\end{array}$ \\
\hline
\end{tabular}


Table 2 The Time Banks Studied

\begin{tabular}{|l|l|l|}
\hline $\begin{array}{l}\text { Timebank.cc } \\
\text { The Hague, Netherlands }\end{array}$ & $\begin{array}{l}\text { Stadin Aikapankki (STAP) } \\
\text { Helsinki, Finland }\end{array}$ & $\begin{array}{l}\text { Rushey Green Time Bank } \\
\text { London, United Kingdom }\end{array}$ \\
$\begin{array}{l}\text { Founded in 2011 } \\
\text { 1200+ members } \\
\text { Operates across the } \\
\text { Netherlands } \\
\text { Approx. 3000 hours } \\
\text { currently in circulation }\end{array}$ & $\begin{array}{l}\text { Founded in 2009 } \\
\text { 3000+ members including } \\
\text { few organizations } \\
\text { Operates in metropolitan } \\
\text { Helsinki } \\
\text { The unit of exchange is tovi } \\
2740 \text { exchanges in 7701 } \\
\text { tovi; approx. 2,8 tovi / } \\
\text { exchange (2013) }\end{array}$ & $\begin{array}{l}\text { Approximately 240 } \\
\text { members } \\
\text { Operates in Rushey Green, } \\
\text { Catford, South London } \\
\text { 30 000 hours of exchanges } \\
\text { (1999-2008); approx. 3000 } \\
\text { hours annually }\end{array}$ \\
\hline
\end{tabular}


Table 3 Time Banks' Framing Strategies.

\begin{tabular}{|c|c|c|c|}
\hline & Timebank.cc & STAP & Rushey Green \\
\hline \multirow[t]{4}{*}{ Diagnostic frame } & \multicolumn{3}{|c|}{ Monetised market system } \\
\hline & & \multicolumn{2}{|c|}{ Health and well-being } \\
\hline & & \multicolumn{2}{|c|}{ Provision systems and social inequality } \\
\hline & \multicolumn{2}{|c|}{ Valuation of work } & \\
\hline \multirow[t]{2}{*}{ Prognostic frame } & \multicolumn{3}{|c|}{ Co-production } \\
\hline & $\begin{array}{c}\text { Alternative economic } \\
\text { model }\end{array}$ & $\begin{array}{l}\text { Democratic } \\
\text { transformation }\end{array}$ & $\begin{array}{l}\text { Institutional position } \\
\text { and reputation }\end{array}$ \\
\hline Motivational frame & $\begin{array}{l}\text { Personal } \\
\text { transformation in a } \\
\text { non-monetary } \\
\text { economy }\end{array}$ & $\begin{array}{l}\text { Political and } \\
\text { economic } \\
\text { realignment in local } \\
\text { decision-making }\end{array}$ & $\begin{array}{l}\text { Neigbourhood help, } \\
\text { friendship, and care }\end{array}$ \\
\hline
\end{tabular}

